\title{
Some aspects of management and outcome of acute coronary heart disease in Oxford region ${ }^{1}$
}

\author{
ROY M. ACHESON AND COLIN SANDERSON
}

From the London School of Hygiene and Tropical Medicine

(1) Over 15 months, 532 consecutive admissions to the CCU at the Radcliffe Oxford were studied; of these 333 were cases of myocardial infarction, and 319 were first admissions for this condition. Information about survival and return to work was collected for 300. A further 30 had artificial pacemakers inserted; there were 141 (26\%) of the 532 cases which did not require the special care offered by the CCU.

(2) Of 300 patients for whom data were available, 27 were recorded as having received DC shock. In hospital, case fatality was significantly higher among those requiring $D C$ shock than among the remainder. Overall the 3-year survival rates were 47 per cent among those receiving shock, and 62 per cent among the remainder, compared with an expected 91 per cent for a population of the same age and sex.

(3) Among men aged under 65 years, 6 of 11 who received shock, compared with 117 (77\%) who did not receive shock, returned to work after leaving hospital.

(4) Rates of admission to the CCU of cases of myocardial infarction per 1000 standardised population among people living in the areas around Oxford City were estimated as being 58 per cent of admission rates of cases among residents of the city.

(5) The case incidence of ventricular fibrillation and the case fatality rate were both higher among those living in the environs than among those living in the city, but these differences were not statistically significant.

(6) It is also concluded that insufficient is known about the factors underlying the general practitioner's decision to commit a case of myocardial infarction to other than short ambulance journeys or about the effects of such journeys on prognosis.

Effective clinical management of myocardial infarction is greatly complicated by the fact that 45 per cent of those who die within 4 weeks of the attack do so within the first hour, and 60 per cent within the first 6 hours after onset (Armstrong et al., 1972). However, if the patient reaches hospital in time, high energy direct current electric shock can prevent death from ventricular fibrillation, and this treatment seems to be most effective when it is carried out in special quiet wards, with a high ratio of skilled staff to each bed, and continuous monitoring of cardiac rhythm to provide immediate warning of abnormalities. The history of the development of these special coronary care units (CCUs) has been well described by Oliver et al. (1967), and evidence adduced from a variety of studies in

${ }^{1}$ The material was presented at a Joint Meeting of the Society for Social Medicine and L'Ecole Nationale de la Santé Publique at Rennes, July 1975.

Received for publication 2 August 1976
Europe, Canada, and the United States (e.g. MacMillan and Brown, 1971; Hofvendahl, 1971; R. J. Donaldson, 1975, personal communication) suggests that the case fatality rates are lower in CCUs than in general medical wards.

The potential value of treatment at home by the family doctor has been shown by Mather and his colleagues $(1971,1976)$ who found in a controlled trial that in the groups that they had been able to allocate at random, 'on average, older patients and those without initial hypertension fared rather better under home care than if they were admitted to hospital'. A study in Teesside (R. J. Donaldson, 1975, personal communication) has lent further support to the view that, taken overall, the prognosis of cases treated at home is at least as good as that of patients treated in hospital, whether in a CCU or not.

These results have raised a number of questions about the roles of the various approaches to treat- 
ment, and on the basis of a descriptive study of patients admitted to the CCU at the Radcliffe Infirmary, Oxford, we have addressed ourselves to two of them. First, how do patients who have had ventricular fibrillation successfully stabilised compare with other cases of myocardial ischaemia in terms of survival and return to work over 3 years? Second, for a CCU sited in a city but surrounded by a rural area, what is the effect of the distance from the patient's home to hospital on referral and survival rates?

\section{Method}

\section{CASE IDENTIFICATION}

The nursing staff of the CCU kept a ward log-book in which they recorded the name and address of every patient admitted. The study population was identified as all the 532 admissions to the CCU listed in this log-book from mid-July 1970 to midOctober 1971, a 15-month period. The policy of the hospital was to admit all suspected cases of myocardial infarction aged under 65 years directly to the CCU.

CLINICAL AND DEMOGRAPHIC INFORMATION Additional data were collected from the following three sources:

(1) Clinical case records at the Radcliffe Infirmary

These were searched for clinical diagnosis, a case only being accepted as myocardial infarction if explicitly described as such. The records were also the source for information on the age and sex of the patient, the place of onset of symptoms, the method used to reach hospital, the date of admission to the CCU, the clinical diagnosis, whether defibrillation or any other procedure which could only readily be provided by a CCU was used, the duration of stay in the unit, and, in cases where the death occurred in hospital, whether this was in the CCU or during the subsequent period in the Radcliffe Infirmary. The majority of the records were examined by R.M.A., and the rest by a medical social worker.

(2) The Office of Population Censuses and Surveys (OPCS)

The central files of this office were searched to determine which of those patients who had left hospital alive had died before 1 January 1975.

(3) Follow-up questionnaire for all cases of myocardial infarction who left hospital alive

This sought to determine whether the relevant admission to the CCU had followed the patient's first, or a subsequent heart attack, and to obtain further details about the method used to reach hospital. It also asked about employment before and after the infarction. The questionnaire was posted early in 1975, either to the patients themselves (209 cases, with an $81 \%$ response) or, for those recorded by OPCS as having died since discharge, to the next of kin (41 cases, with a $76 \%$ response). Information on most of the non-respondents was subsequently obtained by visiting patients' homes, and ultimately survival and most other details were known for 305 out of the 319 patients $(96 \%)$. Of the 14 non-respondents, 2 had left the country and another had gone to Scotland.

For those parts of the analysis which relate to the distance from home to hospital, the catchment area was divided as follows:

(a) Oxford City: The area administered, until the reorganisation of local government in 1974, by the Oxford County Borough. It was 13.7 square miles in size with a population in the 1971 census of 108 805. The Radcliffe Infirmary was the only acute hospital in the city.

(b) Environs: A belt around the city varying in width between about 10 and 15 miles. For the most part its outer boundary follows that of the new County and Health Area of Oxfordshire, but it excludes both the pre-1974 municipal borough and rural district of Banbury, which has its own acute hospital, and the pre-1974 municipal borough and rural district of Henley-on-Thames which falls more naturally within the catchment area of the Reading hospitals. The population of this area was 298870 at the 1971 census. The Radcliffe is the only acute hospital serving the area; but we have no information on the referral practices of the GPs in the environs of Oxford.

\section{(c) Elsewhere}

POPULATION AT RISK

All rates are calculated in terms of the 1971 census.

\section{Results}

DIAGNOSIS, AGE, AND SEX

Table 1 shows that for $18(3 \%)$ of the 532 cases admitted to the CCU during the period, no diagnosis could be found in the records. Patients in this group tended to be gravely ill and it was not possible to be sure from their incomplete records whether in fact they had died in hospital. In a further $181(34 \%)$ cases the diagnosis was not clearly established as being myocardial infarction. Of these, 28 were for routine insertion of a pacemaker, and 12 of them were pacemaker emergencies, so that their management required the special facilities available in a CCU. Thus of the $\mathbf{5 3 2}$ cases, $141(26 \%)$ did not prove to need the special 
Table 1 Number of cases admitted during study period by diagnostic group

\begin{tabular}{lcc}
\hline Diagnosis & No. & Per cent \\
\hline Myocardial infarction & 333 & 63 \\
Emergency admission involving pacemakers & 12 & 2 \\
Routine admission for fitting pacemakers & 28 & 5 \\
Other coronary heart disease & 31 & 6 \\
Non-cardiac chest pain & 22 & 4 \\
Other conditions & 88 & 17 \\
No diagnosis recorded & 18 & 3 \\
\hline Total admissions & 532 & 100 \\
\hline
\end{tabular}

care available in a CCU. There were 333 admissions after myocardial infarction, a total of 319 patients were involved, 10 of whom entered the CCU twice and 1 four times during the study period. We had complete sets of data on address, age, sex, treatment, and survival for 300 of these and their age and sex structure are shown in Table 2. It is worth noting that despite an accepted policy in the unit of not admitting patients aged 65 or more, 62 such patients were treated in the CCU, 21 per cent of the case series.

DC SHOCK, SURVIVAL, AND RETURN TO WORK Survival

Table 3 shows that 27 of the 300 patients were recorded as having received DC shock: 17 of the 27 left hospital alive, and 10 survived until 1 January 1975 . The proportions receiving shock in each age/sex group closely resembled those for all cases in Table 2.

The hospital case fatality for the 273 patients not recorded as having received shock is also shown in Table 3 and this was significantly the lower figure $(P<0.01)$. For those who left hospital alive, the case fatalities between discharge and the end of the follow-up period are given, and though the fatality rate in the interim between discharge and the end
Table 2 Distribution of 300 cases of myocardial infarction by age and sex

\begin{tabular}{lrrrrrr}
\hline & \multicolumn{2}{c}{ Male } & \multicolumn{3}{c}{ Female } & \multicolumn{2}{c}{ Total } \\
Age $(y)$ & No. & $\%$ & \multicolumn{1}{c}{ No. } & $\%$ & No. & $\%$ \\
\hline $25-44$ & 24 & 10 & 2 & 3 & 26 & 9 \\
$45-54$ & 65 & 27 & 13 & 22 & 78 & 26 \\
$55-64$ & 106 & 44 & 28 & 47 & 134 & 45 \\
$65-69$ & 34 & 14 & 13 & 22 & 47 & 16 \\
70 and over & 12 & 5 & 3 & 5 & 15 & 5 \\
\hline Total & 241 & 100 & 59 & 99 & 300 & 101 \\
\hline
\end{tabular}

of the study period for those not receiving DC shock was also lower than for those who received it the difference between the two was not significant. It was estimated from simplified life tables for England and Wales that 8 per cent of the general population with the same age/sex structure as the group receiving DC shock, and 9 per cent of the remainder would have died within the average follow-up period.

\section{Return to work}

For men under 65 years of age, subsequent employment was used as an indicator of the extent of the patients' recovery to full health after their attack and treatment. One hundred and seventeen $(77 \%)$ of those not receiving DC shock for whom information was available had worked since their attacks, with $89(59 \%)$ of them returning to the same job as before. Six of the 11 who received DC shock had worked since discharge, 4 of them in their old jobs (see Table 4).

Place of attack and distance from home to hospital The number of women in the study was small, and they had different patterns of use of the CCU from men, so they were excluded from the analysis that follows.

Table 3 Fatality rates according to whether patient was recorded as having received DC shock

\begin{tabular}{|c|c|c|c|c|c|c|c|c|}
\hline & \multirow[b]{2}{*}{$\begin{array}{l}\text { All } \\
\text { admissions } \\
\text { (1) }\end{array}$} & \multicolumn{3}{|c|}{ In-hospital fatality } & \multicolumn{3}{|l|}{ Subsequent fatality } & \multirow[b]{2}{*}{$\begin{array}{l}\text { Overall fatality } \\
{[(2)+(3)+(6)] /(1)} \\
\%\end{array}$} \\
\hline & & $\begin{array}{l}\text { No. died } \\
\text { in } C C U \\
\text { (2) }\end{array}$ & $\begin{array}{l}\text { No. died } \\
\text { in ward } \\
\text { (3) }\end{array}$ & $\begin{array}{l}\text { Hospital fatality } \\
\text { rate } \\
(4)=[(2)+(3)] /(1) \\
\%\end{array}$ & $\begin{array}{l}\text { No. discharged } \\
\text { alive } \\
(5)=(1)-[(2)+(3)]\end{array}$ & $\begin{array}{l}\text { No. died } \\
\text { before } \\
1.1 .75 \\
(6)\end{array}$ & $\begin{array}{l}\text { Follow-up } \\
\text { fatality rate } \\
(7)=(6) /(5) \\
\%\end{array}$ & \\
\hline \multirow{2}{*}{$\begin{array}{l}\text { DC shock } \\
\text { administered } \\
\text { DC shock not } \\
\text { administered }\end{array}$} & 27 & 5 & 5 & 37 & 17 & 7 & 41 & 63 \\
\hline & 273 & 16 & 21 & 14 & 236 & 67 & 28 & 38 \\
\hline Total & 300 & 21 & 26 & 16 & 253 & 74 & 29 & 40 \\
\hline
\end{tabular}


Table 4 Return to work after discharge (men aged under 65 only)

\begin{tabular}{|c|c|c|c|c|c|c|c|c|c|}
\hline & $\begin{array}{l}\text { Total no. } \\
\text { discharged }\end{array}$ & $\begin{array}{l}\text { No. } \\
\text { emplc } \\
\text { No. }\end{array}$ & $\begin{array}{l}\text { harged alive for whom } \\
\text { ent details known } \\
\%\end{array}$ & $\begin{array}{l}\text { Wor } \\
\text { attac } \\
\text { No. }\end{array}$ & $\begin{array}{l}\text { before } \\
\%\end{array}$ & $\begin{array}{l}\text { Wo } \\
\text { atta } \\
\text { No. }\end{array}$ & $\begin{array}{l}\text { since } \\
\%\end{array}$ & $\begin{array}{l}\text { Ret } \\
\text { sam } \\
\text { No. }\end{array}$ & $\begin{array}{l}d t o \\
\%\end{array}$ \\
\hline DC shock administered & 11 & 10 & 一 & 10 & - & 6 & - & 4 & - \\
\hline DC shock not administered & 161 & 152 & 100 & 133 & 88 & 117 & 77 & 89 & 59 \\
\hline
\end{tabular}

In Table 5 place of attack is classified according to whether it was at home or work or elsewhere. The results of Tunstall Pedoe et al. (1975) for a community study of the overall pattern of incidence (including sudden deaths) are given for comparison.

The Fig. and Table 6 show age-specific admission rates to the CCU per 1000 men in the population and a comparison is made between city dwellers and country dwellers. It can be seen that, as might be expected, there is a consistently and significantly lower rate of admission for patients living in the rural areas than for those living in the city $(P<$ 0.001 ). In the figure, the rates have been converted to an annual base for comparison with $\mathrm{L}$. J. Kinlen's (1972, personal communication) rates for incidence of myocardial infarction in the community.

Among the patients admitted, both the use of DC shock and the fatality rate were higher for those living in the environs of Oxford (Table 7). Though the patterns are quite consistent, the numbers are small and none of the differences are significant at the 5 per cent level.

\section{Discussion}

This study supports the evidence which is widely accepted as indicating not only that DC shock is an effective lifesaver but that it permits people to return to a useful life. Of the 27 patients who were recorded as having received this treatment, 18 left hospital alive and 10 were still alive 3 years later. Moreover, 6 of 11 men of working age returned to work. The numbers are small, and there are insufficient cases for more detailed analysis, but it is doubtful whether without this treatment any of the 27 would have left hospital alive.

The question of distance from hospital is more complex. The overall age-standardised admission rate for acute myocardial infarction for the environs was 67.7 per cent of that for the city, but urban/rural differences seen here could be explained by extreme differences in incidence rates between the two population groups. It is possible to compare published mortality data on ischaemic heart disease (ICD 410-414) for 1971, for Oxford City as against the administrative county of Oxfordshire. (The latter is similar in size to the 'environs' as defined in this study, and the two have about two-thirds of their populations in common.) If the old Oxford Hospital Region is taken as the standard, standardised mortality rates may be estimated as 107 for Oxford City and 98 for the administrative county. Thus if differences in mortality from ischaemic heart

Table 5 Place of attacks (males only)

\begin{tabular}{lrlllllr}
\hline & $\begin{array}{l}\text { Present study } \\
\text { Oxford City }\end{array}$ & \multicolumn{2}{l}{ Environs } & \multicolumn{2}{c}{$\begin{array}{c}\text { Tunstall } \\
\text { Pedoe et al. }\end{array}$} \\
& No. & $\%$ & No. & $\%$ & \multicolumn{2}{c}{ No. } & $\%$ \\
\hline At home & 51 & 57 & 81 & 60 & 438 & 62 \\
At work & 18 & 20 & 20 & 15 & 99 & 14 \\
Elsewhere & 13 & 15 & 16 & 12 & 155 & 22 \\
Not known & 7 & 8 & 18 & 13 & 14 & 2 \\
\hline & 89 & 100 & 135 & 100 & 706 & 100 \\
\hline
\end{tabular}

Table 6 Admission rates per 1000 population to the $C C U$ according to place of residence of patients (men aged 35 to 69 only)

\begin{tabular}{|c|c|c|c|c|c|}
\hline & $\begin{array}{l}\text { Age (y) } \\
35-44\end{array}$ & $45-54$ & $55-64$ & $65-69$ & $\begin{array}{l}\text { Standardised } \\
\text { rates } 1000\end{array}$ \\
\hline $\begin{array}{l}\text { Oxford City } \\
\text { Numbers } \\
\text { Rates per } 1000\end{array}$ & $\stackrel{10}{1 \cdot 8}$ & $\begin{array}{l}23 \\
4 \cdot 1\end{array}$ & $\begin{array}{l}37 \\
6 \cdot 1\end{array}$ & $\stackrel{14}{5 \cdot 8}$ & $4 \cdot 05$ \\
\hline $\begin{array}{l}\text { Environs } \\
\text { Numbers } \\
\text { Rates per } 1000\end{array}$ & $\begin{array}{l}11 \\
0.6\end{array}$ & $\begin{array}{l}38 \\
2 \cdot 2\end{array}$ & $\begin{array}{r}62 \\
4 \cdot 3\end{array}$ & $\begin{array}{l}17 \\
3 \cdot 2\end{array}$ & $2 \cdot 34$ \\
\hline $\begin{array}{l}\text { Environs rate as } \\
\% \text { of city rate }\end{array}$ & 33 & 54 & 71 & 56 & $57 \cdot 8$ \\
\hline
\end{tabular}

^Standardised to the age structure of the old Oxford Hospital Region.

Table 7 Place of residence, administration of DC shock, and fatality rates (males only)

\begin{tabular}{|c|c|c|c|c|c|c|c|}
\hline \multirow{2}{*}{$\begin{array}{l}\begin{array}{l}\text { Place of } \\
\text { residence }\end{array} \\
\\
\text { Oxford city } \\
\text { Environs }\end{array}$} & \multirow{2}{*}{$\begin{array}{l}\begin{array}{l}\text { No. of } \\
\text { patients } \\
\text { admitted }\end{array} \\
\\
89 \\
135\end{array}$} & \multicolumn{2}{|c|}{$\begin{array}{l}\text { Cases } \\
\text { receiving } \\
\text { DC shock }\end{array}$} & \multicolumn{2}{|c|}{$\begin{array}{l}\text { Hospital } \\
\text { fatality } \\
\text { rate }\end{array}$} & \multicolumn{2}{|c|}{$\begin{array}{l}\text { Follow-up } \\
\text { fatality } \\
\text { rate }\end{array}$} \\
\hline & & $\begin{array}{c}\text { No. } \\
5 \\
16\end{array}$ & $\begin{array}{l}\% \\
5 \cdot 6 \\
11 \cdot 8\end{array}$ & $\begin{array}{l}\text { No. } \\
11 \\
23\end{array}$ & $\begin{array}{l}\% \\
12 \cdot 3 \\
17 \cdot 0\end{array}$ & $\begin{array}{l}\text { No. } \\
19 \\
34\end{array}$ & $\begin{array}{l}\% \\
24 \cdot 3 \\
30 \cdot 4\end{array}$ \\
\hline
\end{tabular}

*Calculated in the same way as in Table 3. 


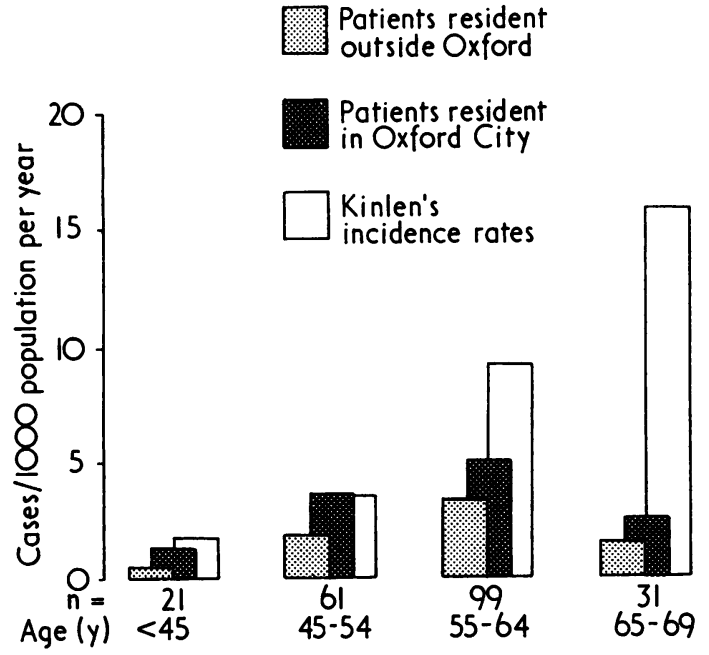

Fig. Age specific case referral rates (per 1000 per year) for male patients resident in Oxford City and environs, compared with annual incidence rates in the Oxford area estimated by L. F. Kinlen (1972, personal communication). Note that the referral rates are always higher for the city than for the environs, but that for both areas they fall as a proportion of the incidence after the age of 55 years. Kinlen included sudden death in his estimate of incidence so that part of the difference between total incidence and cases referred results from the fact that some patients will not have survived to have been referred.

disease can be taken as an index of differences in the incidence of myocardial infarction, this would explain a difference in admission rates of about 10 per cent.

A second factor that could affect referral patterns is standard of housing. Clearly, it is more difficult to care satisfactorily for a case of myocardial infarction in a substandard home than in an adequate one. Again we had no direct data on this for patients in the study, but the census figures in Table 8 suggest that differences in this respect were small; though the houses in the city are generally slightly better equipped, they are a little more crowded. On the question of community support, the proportion of people living alone was twice as high in the city as in the environs, but was a relatively small fraction of the overall population, and there was no difference in the proportions for male pensioners, i.e. men aged 65 and over. A further relevant point is that some patients in the environs may have been taken to other hospitals. The extent of this 'leakage' is being investigated; but given the definition of the areas and the locations of alternative hospitals this effect is likely to have been very small. Thus, though some of the discrepancy may be discounted against differences in incidence, our data do seem to indicate that a patient whose home is relatively remote is less likely to be admitted to the CCU than someone living in Oxford.

Table 5 shows that a slightly greater proportion of urban than rural dwellers among the patients had their attack away from home. One explanation is that city dwellers who have their attacks at work or in the street are normally taken straight to hospital, whereas country dwellers with attacks in similar circumstances are more likely to be taken home. We do know that the medical staff at British Leyland always send a case of acute myocardial infarction straight to the Radcliffe Infirmary (W. G. White, 1974, personal communication; R. M. Acheson, P. Baxter, and C. B. Sanderson, unpublished data).

What of the patients who are admitted in spite of the fact that their home is some distance from the CCU? Our data here once more are scanty, but reference to Kinlen (1969) and information provided to us by the ambulance service suggests that the difference in journey time for city dwellers as against country dwellers is on average of the order of 20 minutes though a few of the cases in this series probably travelled for nearly an hour. In general, time in transit is short relative to overall delay between onset and treatment (Armstrong et al., 1972; Kinlen, 1973), but if anything the proportion of cases requiring DC shock might be expected to be a little higher among the city than the country dwellers. The opposite was found to be the case and

Table 8 Comparison of housing conditions and household types between Oxford City and its environs as classified in 1971 census

\begin{tabular}{|c|c|c|c|c|c|}
\hline & Households & & Population & & \\
\hline & $\begin{array}{l}\text { With no hot water } \\
(\%)\end{array}$ & $\begin{array}{l}\text { With no fixed } \\
\text { bath/shower } \\
(\%)\end{array}$ & $\begin{array}{l}\text { In households with } \\
\text { over } 1 \text { person/room } \\
(\%)\end{array}$ & $\begin{array}{l}\text { In 1-person } \\
\text { households } \\
(\%)\end{array}$ & $\begin{array}{l}\text { Male persons in } \\
1 \text {-person house- } \\
\text { holds (\%) }\end{array}$ \\
\hline Oxford city & $4 \cdot 0$ & $5 \cdot 0$ & $12 \cdot 1$ & 8.5 & $11 \cdot 6$ \\
\hline Oxford Administrative County & $5 \cdot 2$ & $5 \cdot 9$ & $9 \cdot 8$ & $4 \cdot 4$ & $11 \cdot 6$ \\
\hline
\end{tabular}


though this was not a significant difference, when it is taken together with the lower admission rates and higher fatality rates it does suggest that it should not be dismissed lightly.

Country patients may have been selected because their GPs considered their cases were too severe to be managed at home. Alternatively, the ambulance journey itself may have been responsible for triggering off a series of events leading to ventricular fibrillation that would not otherwise have occurred. This second explanation is more consistent with the observation of Rose (1975) that despite the success of defibrillation, and despite the sharp increase in admission rates of cases of coronary heart disease to hospital over the past decade, death rates from this condition both in the general population and in hospital remain unchanged in England and Wales.

Between 30 and 40 per cent of attacks take place away from home (Kinlen, 1969; Tunstall Pedoe et al., 1975) and some of these will inevitably be brought into hospital. Others will have to be admitted for social reasons, and in general it seems that prognosis is probably better in a CCU than in a general ward. What about the remainder? Mather et al. (1976) have already provided some pointers, but should patients who have just suffered a myocardial infarction be subjected to a lengthy ambulance journey if it can reasonably be avoided? And were the Royal College of Physicians and the British Cardiac Society (1975) wise in emphasising the importance of CCUs without giving more consideration to what could be done to improve facilities outside the hospital?

We are grateful to Dr Grant Lee and Professor Peter Sleight for allowing us to analyse the records of the patients under their care. The research was supported by a grant from D.H.S.S.

\section{References}

Armstrong, A., Duncan, B., Oliver, M. F., Julian, D. G., Donald, K. W., Fulton, M., Lutz, W., and Morrison, S. L. (1972). Natural history of acute coronary heart attacks. A community study. British Heart fournal, 34, 67-80.

Hofvendahl, S. (1971). Influence of treatment in a coronary care unit on prognosis in acute myocardial infarction. Acta Medica Scandinavica, Suppl. 519.

Kinlen, L. J. (1969). A community study of myocardial infarction and sudden death. Thesis for the D.Phil. degree, Oxford.

Kinlen, L. J. (1973). Incidence and presentation of myocardial infarction in an English community. British Heart Fournal, 35, 616-622.

Mather, H. G., Pearson, N. G., Read, K. L. Q., Shaw, D. B., Steed, G. R., Thorne, M. G., Jones, S., Guerrier, C. J., Eraut, C. D., McHugh, P. M., Chowdhury, N. R., Jafary, M. H., and Wallace, T. J. (1971). Acute myocardial infarction: home and hospital treatment. British Medical fournal, 3, 334-338.

MacMillan, R. L., and Brown, K. W. G. (1971). Comparison of the effects of treatment of acute myocardial infarction in a coronary unit and on a general medical ward. Canadian Medical Association fournal, 105, 1037-1040.

Mather, H. G., Morgan, D. C., Pearson, N. G., Read, K. L. Q., Shaw, D. B., Steed, G. R., Thorne, M. G., Lawrence, C. J., and Riley, I. S. (1976). Myocardial infarction: a comparison between home and hospital care for patients. British Medical fournal, 1, 925-929.

Oliver, M. F., Julian, D. G., and Donald, K. W. (1967). Problems in evaluating coronary care units. American fournal of Cardiology, 20, 465-474.

Rose, G. (1975). The contribution of intensive coronary care. British fournal of Preventive and Social Medicine, 29, 147-150.

Royal College of Physicians of London and the British Cardiac Society (1975). The care of the patient with coronary heart disease. Fournal of the Royal College of Physicians of London, 10, 5-46.

Tunstall Pedoe, H., Clayton, D., Morris, J. N., Brigden, W., and McDonald, L. (1975). Coronary heart attacks in east London. Lancet, 2, 833-838.

Requests for reprints to Professor Roy M. Acheson, Department of Community Medicine, University of Cambridge, Addenbrooke's Hospital, Hills Road, Cambridge CB2 2QQ. 